\title{
MENERAPKAN PENJAMINAN KUALITAS DALAM MUTU UPAYA DALAM MENINGKATKAN BUDAYA ORGANISASI DI PERUSAHAAN
}

\author{
Nandri Nur Ahmad Fahmi \\ Universitas Nurul Jadid (UNUJA) Paiton Probolinggo \\ Email: Nandri Nur Ahmad Fahmi@gmail.com
}

\begin{abstract}
Abstrak
Budaya Kualitas merupakan suatu sistem yang kondusif yang membahas tentang kepuasan pelanggan yang melibatkan dengan yang berpihak.

Penerapan Budaya Kualitas itu sendiri tidak lepas dari metode-metode yang diperlukan dalam upaya meningkatkan manajemen mutu di suatu perusahaan itu sendiri.

Oleh karena itu tujuan Budaya Kualitas itu sendiri yakni untuk mengatahui kualitas manajamen mutu dalam kepuasan pelanggan dalam suatu organisasi di perusahaan.
\end{abstract}

\section{PENDAHULUAN}

Banyak terjadi masalah di era modernisasi saat ini terutama tentang penjaminan kualitas di dalam suatu oraganisasi itu sendiri, maka dari itu kepuasan pelanggan dalam suatu organisasi harus ada yang namanya kondusif, renponsif dan jaminan yang nyata. kualitas pelayanan dalam suatu organisasi di perusahaan itu banyak mempengaruhi beberapa aspek, salah satunya yaitu cara mengkondisikannya dalam suatu madrasah untuk menjadikan penjaminan pelanggan organisasi di perusahaan itu sendiri.

Rendahnya penjaminan kualitas dalam suatu organisasi di peusahaan akan berdampak kepada budaya kualitas itu sendiri, oleh karena itu standart akan manajemen mutu itu sendiri sangat perlu di aplikasikan karena mengingat akan 
ketatnya penjaminan kepuasan pelanggan di dalam suatu organisasi itu sendiri.dan patut kiranya manajemen mutu kualitas yang bersifat kondusif,responsive,dan jaminan yang nyata itu harus diaplikasikan

\section{A. Definisi Kualitas Budaya}

Hambatan budaya menyebabkan beberapa faktor yang terjadi dalam meningkatkan kualitas budaya. Maka dari itu terdapat banyak sekali upaya dalam meningkatkan budaya organisasi yang di mulai dari planning, actuating, pelatihan dan penerapan progam yang sudah direncanakan sebelumnya. Tapi banyak sekali apa yang sudah di usahakan sebelumnya tidak apa yang di harapkan sebelumya dalam arti rata tidak ada peningkatan dalam budaya organisasi. Dari hal tersebut meskipun menganggap bahwasannya budaya organisasi yang sudah direncanakn sebelumnya tidak baik dari organisasi lainnya, tapi beberapa realita yang ada dari lembaga ataupun perusahaan mengalami yang namanya keburukan dalam hal keuangan ${ }^{1}$. Pada era medernisasi banyak sekali melakukan perubahan dari segi praktek manajemen dan organisasi, tapi dalam melakukan perubahan itu banyak sekali yang terabaikan. Jadi dari hal tersebut sistem pemerintahan banyak sekali melakukan perubahan, maka dari itu akan terjadi hal yang sama.

Mengenal budaya kualitas untuk pelayanan yang utama, harus diawali dengan pemahaman budaya organisasi itu sendiri. Budaya organisasi merupakan perwujudan suatu pernyataan dalam sehari-hari dari tradisi yang sudah ada. Dalam hal ini bisa terlihat dari segi perilaku karyawan atau anggota dalam kinerjanya sehari-hari di organisasi itu sendiri. Banyak terjadi perbedaan antara gambaran tujuan organisasi agar bagaimana organisasi dianut dalam tingkah laku kayawaan atau anggota dalam kesehariannya. Jadi tidak heran apabila karyawan atau pegawai tidak memfokuskan terhadap kepuasaan pelanggan, ${ }^{1}$ maka disitulah terjadi banyak problematika.

\footnotetext{
${ }^{1}$ Creech, Bill. Lima Pilar TQM. Dialihbahasakan oleh Alexander sindoro.Jakarta:bina rupa,1996
} 
Budaya organisasi dalam pembentukannya disini memiliki lima hal diantaranya: ${ }^{2}$,

1. Lingkungan Organisasi

Lingkungan organisasi merupakan suatu bentuk yang penting dalam pelaksanaannya. Di dalam organisasi yang selalu melakukan reformasi akan terpacu terhadap reformasi itu sendiri. Adapun sebaliknya jika lingkungan organisasi tersebut mendukung (baik) tidak akan melakukan perubahan tapi tetap mempertahankan budaya organisasi yang mana lingkungan organisasi tersebut baik.

\section{Ponten Organisasi}

Ponten Organisasi adalah pemaparan terhadap apa yang sudah di anggap penting dari organisasi. Yang menjadi hal yang sangat penting dalam organisasi ialah keberhasilan yang sudah direncanakan sebelumnya. Maka dari itu keberhasilan merupakan ponten organisasi yang menjadikan budaya dalam organisasi budaya itu sendiri berkualitas.

\section{Pola Kedudukan Budaya}

Pola Kedudukan Budaya merupakan orang yang mana memiliki ponten dalam organisasi sehingga orang tersebut menjadi cerminan dalam organisasi.

Demikian berharganya seseorang tersebut, maka ketika orang yang menjadi model atau panutan tersebut pensiun atau meninggal dunia, seringkali orang tersebut menjadi legenda organisasi.

\section{Pemancar Budaya}

Pemancar Budaya adalah tujuan untuk membentuk karakter didalam budaya organisasi yang diturunkn secara turun menurun ke generasi selanjutnya.

\footnotetext{
${ }^{2}$ Setiawan wicaksono.2006.Pengaruh implementasi total quality management (TQM) terhadap budaya kualitas (studi pada PT. Hari Terang Industry-surabaya).19-20
} 
Dapat kita simpulkan keempat unsur yang telah di paparkan di atas yaitu tentang pembentukan karakter dalam suatu organisasi di dalam perusahaan.

Menurut para pakar ahli pendidikan mengatakan definisi budaya kualitas yaitu: ${ }^{3}$

Budaya kualitas merupakan suatu organisasi yang membangun suatu tempat menjadi kondusif.

Para pakar ahli pendidikan berpendapat untuk mengetahui suatu karakter di dalam organisasi itu ada beberapah hal diantaranya:

1. Sikap pegawai di dalam suatu lingkungan organisasi.

2. saran dari konsumen untuk untuk meningkatkan kualitas.

3. Para pekerja juga ikut berperan aktif dalam menigkatkan kualitas peusahaan.

4. para pegawai harus bekerja kelompok di dalam suato organisasi

5. Para atasan harus tegas dalam hal mempimpin peusahaan dan harus siap bertanggung jawab apa-apa yang terjadi didalam suatu perusahhan itu sendiri.

6. SDM harus dimaksimalkan untuk kebutuhan organisasi agar ttap stabil dalm meningkatkan perusahaan.

7. Meningkat karakter para pegawai perusahaan itu perlu ditingkatkan untuk bersaing akan halnya kemanajemenan perusahaan.

8. Reward sedianya diberikan kepada para pekerja untuk meningkatkan kerja di dalam perusahan.

Dapat di simpulkan dari pemaparan di atas, budaya kualitas merupakan suatu pendidikan karakter dalam suatu organisasi untuk meningkatkan kualitas di dalam peusahaan itu sendiri.

${ }^{3}$ Amin ibrahim.pokok-pokok Administrasi publik dan budaya kualitas.(Bandung:Refika Aditama,2008),15-16) 


\section{B. Meningkatkan Budaya Kualitas}

Meningkatkan budaya kualitas memang tidak gampang membolak balikan tangan tapi didalam suatu organisasi untuk meningkatkan budaya kualitas harus yang ada namanya continue. Secara kasat mata budaya dan kualitas saling berkaitan satu sama lain. Oleh karena itu keberhasilan membangun budaya kualitas memerlukan adanya perubahan budaya. Para pakar pendidikan memaparkan beberapa alasan utama dan perubahan budaya harus dijalankan karena mengingat pentingnya budaya kualitas itu sendiri.diantaranya: ${ }^{4}$

a. Perubahan tidak bisa berjalan dengan keadaan lingkungan tidak ramah atau ada intimidasi.

Pimpinan yang tidak pernah melakukan kontroling ke lapangan, pegawai yang selalu disibukkan dengan permasalahan pribadi, kenaikan gaji, promosi, mengacuhkan masukan atau saran anggota team adalah contoh-contoh keadaankeadaan yang kurang kondusif untuk melakukan perubahan kualitas.

b. Mengubah kearah kualitas prima secara keseluruhan membutuhkan waktu.

Seringkali pelaksanaan progam membangun budaya kualitas tidak langsung memberi hasil yang langsung prima. Selalu membutuhkan waktu yang kadang tidaklah pendek. Hal ini yang selalu mempengaruhi proses dengan munculnya resistensi dari pegawai-pegawai yang tidak percaya dan tidak setuju dengan diperlukannya perubahan. Dibutuhkan kesabaran agar seluruh pihak sukarela menjalani tahapan-tahapan proses dan konsistensi dalam menerapkannya.

c. Merupakan suatu yang sulit untuk memperbaiki hal-hal yang telah berlalu.

Bagi pegawai yang sudah lama bekerja umumnya sudah tidak menarik lagi bagaimana dari waktu ke waktu genderang perubahan ditabuh dan lama kemudian terbiarkan lalu menghilang. Kemudian datang lagi pimpinan dengan konsep perubahan yang baru, gegap gempita untuk kemudian berlalu dan dilupakan juga. Oleh sebab itu dibutuhkan ketelatenan dalam mengenalkan dan melakukan setiap

${ }^{4}$ Soewarso,Hardjosoedarmo. Budaya Kualitas. (Yogyakarta, Andi Yogyakarta) 
perubahan. Dan bagaimanapun budaya hasil perubahan di masa lalu masih tetap melekat dan tidak gampang berganti oleh budaya baru yang dikenalkan.

Membangun budaya kualitas ini membutuhkan fondasi budaya organisasi yang kokoh, maka perlu diperhatikan langkah-langkah berikut: ${ }^{5}$

a. Memahami latar belakang sejarah budaya yang saat ini ada.

Budaya yang ada sekarang ini dibangun dengan mencanangkan nilai-nilai yang baik untuk organisasi. Waktu dan perubahan yang membuat seakan-akan budaya yang ada sekarang ini menjadi lebih buruk. Dengan memahami latar belakang bagaimana budaya saat ini terbentuk, maka terdapat landasan yang kuat untuk memutuskan untuk mempertahankan atau mengubahnya.

b. Jangan mengacak system yang sudah ada tapi lakukan peningkatan.

Melakukan suatu peningkatan harus memahamidulu apa yang salah dengan yang ada. Memikirkan dengan apa dan bagaimana mengubahnya tujuan ini dilakukan untuk memperbaiki dan meningkatkan kualitas.

c. Siap untuk mendengarkan dan mengamati.

Karena yang dirubah menyangkut manusia, pegawai, maka harus siap untuk mendengarkan bagaimana respon atau pendapat pegawai dengan perubahan. Teliti dengan seksama dan bila perlu lakukan pengamatan untuk mendapatn apa yang diharapkan mereka tapi tidak disampaikan, hanya disimpan dan menjadi ganjalan di hati mereka.

d. Libatkan seluruh pegawai yang terkena akibat perubahan.

Respon alamiah bila seseorang melakukan resistensi terhadap perubahan karena perubahan tersebut menyangkut dirinya. Oleh karena itu satu-satunya cara yang dianggap paling efektif dalam melakukan perubahan adalah dengan memastikan bahwa seluruh pegawai dilibatkan dalam proses perencanaan dan implementasi

${ }^{5}$ Wilkinson, A.: M. Marchington, J. Goodman and P. Ackers. 1992. Budaya Kualitas. Human Resource Management journal 2(4): 1-20 
perubahan sehingga mereka akan ikut dan menyelaraskan diri terhadap perubahan tersebut.

Hendaknya budaya kualitas yang terbentuk menjadi karakter organisasi, menjadi budaya organisasi. Budaya kualitas tersebut bila mengacu pada pendapat Greenberg dan Baron semestinya memiliki tiga fungsi utama, yaitu ${ }^{6}$ :

1. Menjadi identitas seluruh pegawai;

2. Mendorong peningkatan komitmen terhadap misi organisasi; dan

3. Mengklarifikasi serta menegaskan standard perilaku semua pegawai.

\section{Tindakan Perubahan Menuju Budaya Kualitas}

Tindakan-tindakan untuk perubahan menuju budaya kualitas yaitu dengan membutuhkan perubahan.Untuk menuju perubahan yang berkualitas maka harus di buat tindakan-tindakan perubahan organisasi secara tepat untuk membangun budaya kualitas, diantaranya.: ${ }^{7}$

1. Melakukan identitas perubahan di dalam organisasi.

2. Merencanakan keadaan yang telah di rancang.

3. Membentangkan rancangan untuk menuju perubahan yang lebih baik.

4. Menetapkan pihak yang bersangkutan untuk menuju perubahan dengan cara pendekatan secara emosional dengan pegawai.

5. Mengerjakan identitas pegawai secara kondusif untuk perubahan yang dapat dilakukan secara bertahap.

6.Mengikut sertakan pegawai secara emosional dalam suatu organiasi untuk perubahan yang lebih maju.

${ }^{6}$ Hasan Baharun \& Zamroni, Manajemen Mutu, iktiar dalam meningkatkan budaya kualitas melalui pendekatan Balanced Scorecard,(Tulungagung, Akamedia pustaka,2017)148

${ }^{7}$ Soewarso,Hardjosoedarmo. Budaya Kualitas. (Yogyakarta, Andi Yogyakarta) 169 
7. Melaksanakan pendekatan secara emosinal guna untuk Melakukan perubahan yang kondusif.

8. Mengaplikasikan perubahan secara terbuka kepada pegawai dengan bertahap.

9.Melakukan motivasi kepada para pegawai secara bertahap untuk membangunkan rasa semangat untuk menuju perubahan yang lebih baik. 


\section{Penutup}

pelayanan organisasi yang prima atau berkualitas diperoleh dari budaya organisasi yang memang menetapkan pelayanan yang berkualitas sebagai ciri atau karakter organisasi tersebut. Membangun budaya kualitas pada organisasi memerlukan perubahan budaya yang tidak mudah dilakukan. Resistensi terhadap budaya baru dan sikap apatis pegawai terhadap perubahan-perubahan yang mungkin seringkali dilakukan namun selama ini tanpa akhir yang jelas seringkali menjadi penghalang proses pembentukan budaya kualitas yang direncanakn organisasi. Tahapan-tahapan mengkonversi ke budaya kualitas harus secara cermat dilakukan yang pada intinya harus melibatkan seluruhs pegawai yang secara logis mereka semua akan terdampak dan mengalami perubahan budaya yang dilakukan organisasi.

Penelitian yang mendalam dan komprehensif kiranya perlu dilakukan untuk mengetahui apakah layanan prima yang sejauh ini dicanangkan pada birokrasi pemerintahan sudah menjadi budaya organisasi ataukah masih berupa tindakan temporer organisasi. Penelitian lainnya bisa lebih ke aspek fundamental antara lain apakah reformasi birokrasi memiliki konsep perubahan budaya organisasi. 


\section{DAFTAR PUSTAKA}

Setiawan wicaksono.2006.Pengaruh implementasi total quality management (TQM) terhadap budaya kualitas (studi pada PT. Hari Terang Industry-surabaya).

Creech, Bill. Lima Pilar TQM. Dialihbahasakan oleh Alexander sindoro.Jakarta:bina rupa,1996

Amin ibrahim.pokok-pokok Administrasi publik dan budaya kualitas.(Bandung:Refika Aditama,2008), 15-16)

Soewarso,Hardjosoedarmo. Budaya Kualitas. (Yogyakarta, Andi Yogyakarta)

Wilkinson, A.: M. Marchington, J. Goodman and P. Ackers. 1992. Budaya Kualitas. Human Resource Management journal 2(4): 1-20 